\title{
A kinetic study of the basic hydrolysis of 2-phenylethyl nitrite in the presence of borate buffer and $\beta$-cyclodextrin
}

\author{
Francesca D’Anna, ${ }^{a^{*}}$ M. Liria Turco Liveri ${ }^{\mathrm{b}}$, and Renato Noto ${ }^{\mathrm{a}}$ \\ ${ }^{a}$ Dipartimento di Chimica Organica “E. Paternò”, ${ }^{b}$ Dipartimento di Chimica Fisica \\ Viale delle Scienze, Parco d'Orleans II, 90128 Palermo, Italy \\ E-mail: rnoto@unipa.it
}

Dedicated to Professor Domenico Spinelli on his $70^{\text {th }}$ birthday

(received 02 Oct 02; accepted 18 Dec 02; published on the web 26 Dec 02)

\begin{abstract}
The kinetics of the hydrolysis of 2-phenylethyl nitrite have been studied in basic aqueous solutions (borate buffer) in the absence and presence of $\beta$-cyclodextrin. The observed kinetic trends show that the hydrolysis reaction consists of at least three subsequent processes. The first is a fast acid-base reaction between the boron atom of boric acid and oxygen atom of the alkyl nitrite. The second one should be the nucleophilic attack of hydroxyl ion on the alkyl nitrite. The last process could be referred to as a combination of transfer of hydrogen acid to a water molecule followed by ruptures of nitrogen-oxygen and boron-oxygen bonds. The effect of $\beta-$ cyclodextrin on each process is also discussed.
\end{abstract}

Keywords: Basic catalysis, hydrolysis, cyclodextrin, alkyl nitrite

\section{Introduction}

Cyclodextrins (CDs) are widely used as hosts, owing to their ability to form, in aqueous solution inclusion complexes with small- and medium-sized organic molecules. ${ }^{1}$ This process enables the solubilization of compounds which are otherwise water-insoluble. ${ }^{2}$ Chemical reactions pertaining to the included guest may take place, and the effects of inclusion on the reactivity vary widely depending on the nature of the guest, the CD, and the reaction examined. ${ }^{3}$ The CD may take part directly in the reaction, interacting with substrate through one (or more) hydroxylic group (or their conjugate base, depending on the $\mathrm{pH}$ value) placed on the secondary rim. ${ }^{4}$ It has been found that the rate of the reaction is either greatly reduced, which has led to the use of CDs as stabilizers, ${ }^{5}$ or increased owing to their effect on enthalpic and/or entropic factors. ${ }^{6}$ Moreover, the CD host can merely provide a confined reaction environment that is less polar than bulk solvent, ${ }^{7}$ thus operating as a totally different reaction medium. Functionalized CDs operating as 
enzymes have a hydrophobic cavity and suitable functional groups that can promote chemical reactions by bringing together the reacting groups under the special conditions of the enzymesubstrate complex. ${ }^{8}$ Thus, they are very promising materials. Recently we have addressed our attention to cyclodextrins, particularly to the functionalized ones, ${ }^{9}$ and think that it can be interesting to study the $\beta$-cyclodextrin borate ${ }^{10}$ among the functionalized CDs Indeed this, having seven $>\mathrm{B}-\mathrm{OH}$ groups on the secondary rim, can act as an effective medium for base-catalyzed reactions.

In order to gain information on the effect of this cyclodextrin on organic reactions we have undertaken a preliminary study on the base-catalyzed hydrolysis of alkyl nitrites. This reaction is important for its biological implications; ${ }^{11}$ alkyl nitrites release nitric oxide that acts on muscle relaxation. Furthermore, the alkyl nitrites are important in the control of blood pressure owing to their well-known properties as vasodilators. The main subject of this paper is the kinetic study of the hydrolysis (Scheme 1) of 2-phenylethyl nitrite (1) at $298 \mathrm{~K}$, in basic media (hydroxyl ion concentration in the range $1.76 * 10^{-6}-9.31 * 10^{-4} \mathrm{~mol}^{-1}$ ) realized by using various boric acidborate ratios in the absence and presence of $\beta$-CD. The kinetic experiments have been carried out under pseudo-first-order conditions. Moreover, in order to have data comparable with those we shall collect in the presence of $\beta$-CD borate, for kinetic runs carried out in the presence of $\beta-C D$ a ratio $\beta-C D$ : boric acid of 1 to 7 was adopted.

Previously, the hydrolysis of 2-phenylethyl nitrite and some other alkyl nitrites has been studied $^{12}$ in the presence of $\beta-\mathrm{CD}$ in both acidic aqueous solution at $\mathrm{pH} 4.89$, and in more basic aqueous solutions (hydroxyl ion concentration in the range $0.03-1.1 \mathrm{~mol}^{-1}$ ).

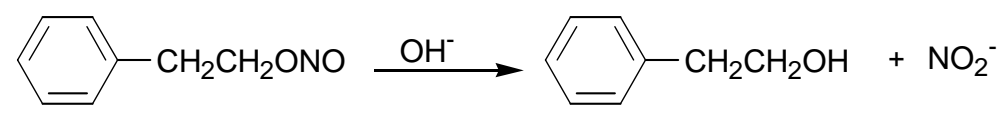

(1)

\section{Scheme 1}

\section{Results and Discussion}

The complete course of the absorbance as a function of time for the basic hydrolysis of $\mathbf{1}$ in the presence of acid boric-borate buffer is shown in Figure 1. 


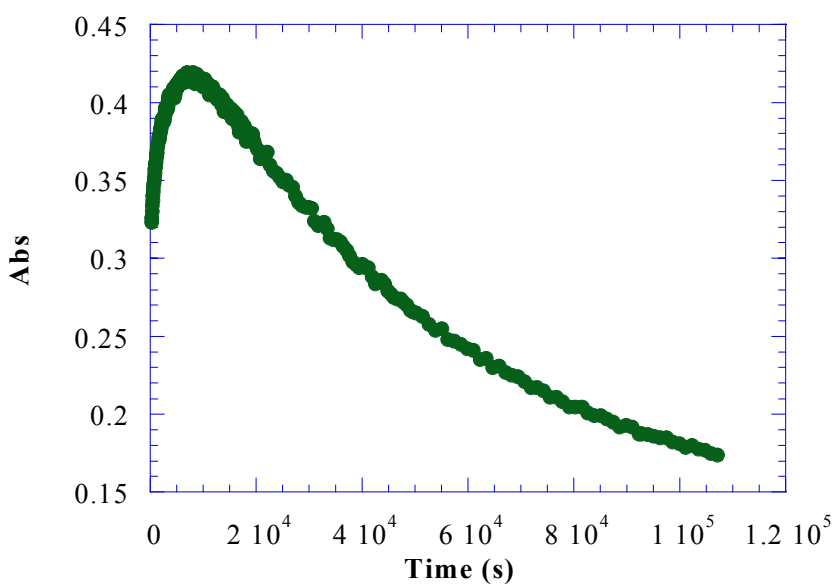

Figure 1. Typical experimental trace obtained at $240 \mathrm{~nm}$ for the basic hydrolysis of 2phenylethyl nitrite $\left(0.0004 \mathrm{~mol} \mathrm{l}^{-1}\right)$ at $298 \mathrm{~K} . \mathrm{C}_{\mathrm{H} 3 \mathrm{BO} 3}=0.0077 \mathrm{~mol} \mathrm{l}^{-1}, \mathrm{C}_{\mathrm{B}(\mathrm{OH}) 4}{ }^{-}=0.0063 \mathrm{~mol} \mathrm{l}^{-1}$, $\mathrm{C}_{\mathrm{OH}^{-}}=8 * 10^{-6} \mathrm{~mol} \mathrm{l}^{-1}$.

It can be seen that the curve does not show the typical trend of a simple kinetic process. It seems that at least two kinetically relevant steps are responsible for the observed trend. Moreover, at $\mathrm{t}=0$ an absorbance value of 0.320 has been detected. This value is lower than the expected one, $\mathrm{Abs}=0.450$. This behavior suggested to us that a very fast process has to be operative. In order to verify this hypothesis we have studied the kinetics of the reaction by using a stopped-flow apparatus. This result is reported in Figure 2.

Curves like that reported in Figure 1 were recorded in the range of $\mathrm{pH}(8.24-0.97)$ and $\beta$-CD $\left(0.001-0.006 \mathrm{~mol} \mathrm{l}^{-1}\right)$ in the presence of boric acid-borate buffer. Kinetic runs carried out either in the absence of buffer or in the presence of phosphoric acid-phosphate buffer showed the typical trend for a first-order reaction (see Figure 3).

These trends suggested to us that it is reasonable to suppose that some interaction between boric acid and alkyl nitrite must occur.

The above experimental data can be explained by considering that the fast reaction is an acidbase reaction between the boron atom (hard acid) of boric acid and an oxygen atom (hard base) of the alkyl nitrite. A less favorable interaction should be the hard-soft between boron and nitrogen atoms. The B-O and B-N bond energies, 809 and $389 \mathrm{~kJ} / \mathrm{mol}$, respectively ${ }^{13}$ can give a measure of the extent of the two different interactions. The hard-hard interaction is favored, as demonstrated by the fact that the acid hydrolysis of alkyl nitrites (hard-hard interaction between $\mathrm{H}_{3} \mathrm{O}^{+}$and oxygen atom of alkyl nitrite) is quite a fast process, faster than alkaline hydrolysis (hard-soft interaction between $\mathrm{OH}^{-}$and nitrogen atom of alkyl nitrite). ${ }^{12}$ Really, two different boron-oxygen interactions between boric acid and alkyl nitrite, are possible (Scheme 2) but only one, $(\mathbf{C})$, is able to give hydrolysis product. 


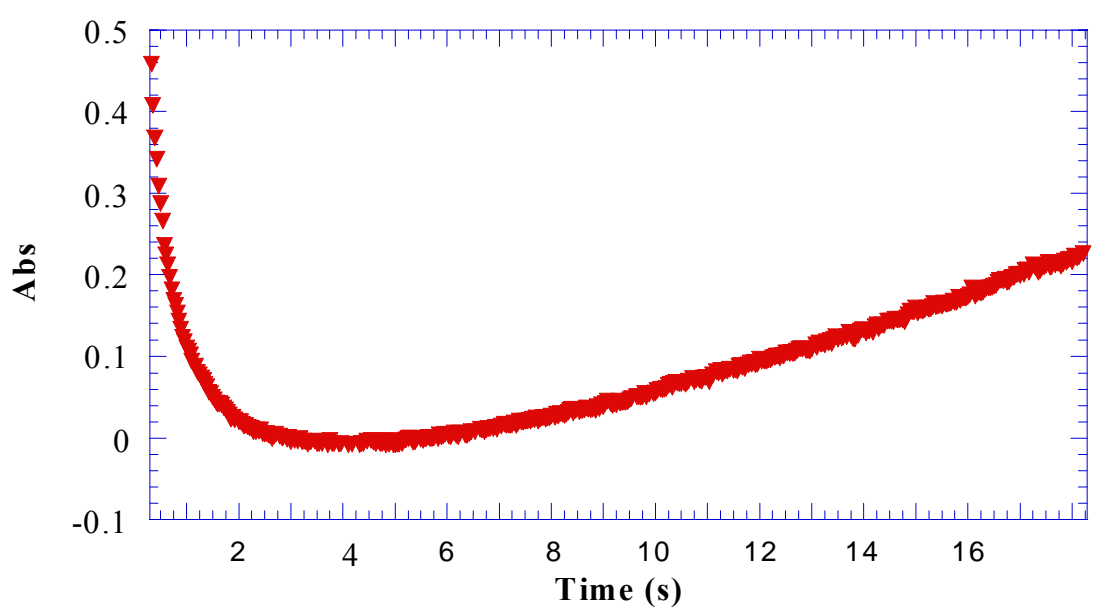

Figure 2. Typical experimental trace obtained at $240 \mathrm{~nm}$ for the first fast step of the basic

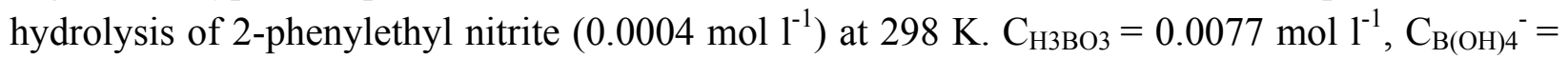
$0.0063 \mathrm{~mol} \mathrm{1}^{-1}, \mathrm{C}_{\mathrm{OH}}{ }^{-}=8 * 10^{-6} \mathrm{~mol} \mathrm{1}^{-1}$.

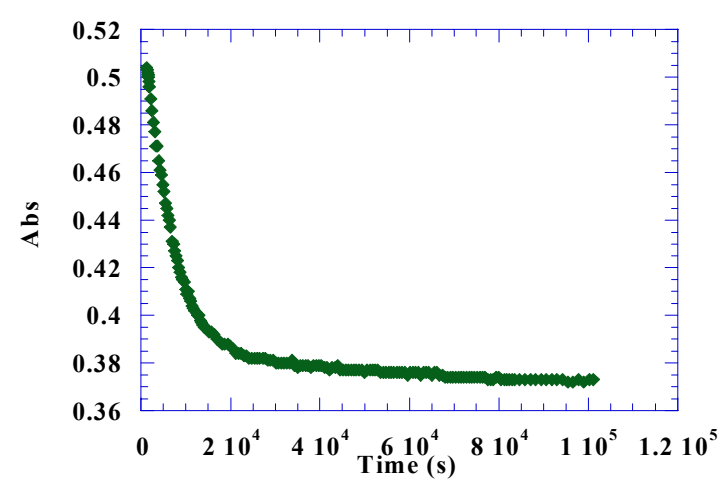

(a)

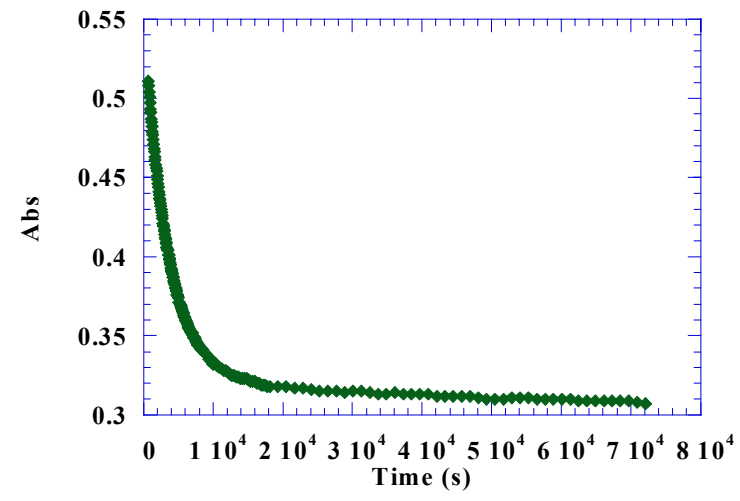

(b)

Figure 3. Typical experimental trace obtained for the basic hydrolysis of 2-phenylethyl nitrite $\left(0.0004 \mathrm{~mol} \mathrm{l}^{-1}\right)$ in the presence of: $(\mathbf{a})$, phosphate buffer $\mathrm{C}_{\mathrm{NaH} 2 \mathrm{PO} 4}=0.0063 \mathrm{~mol} \mathrm{l}^{-1}, \mathrm{C}_{\mathrm{Na} 2 \mathrm{HPO} 4}=$ $0.0076 \mathrm{~mol} \mathrm{l}^{-1}, \mathrm{C}_{\mathrm{OH}}{ }^{-}=1.6 * 10^{-7} \mathrm{~mol} \mathrm{l}^{-1} ;(\mathbf{b})$, hydroxyl ion $\mathrm{C}_{\mathrm{OH}}{ }^{-}=0.0008 \mathrm{~mol} \mathrm{l}^{-1}$. 


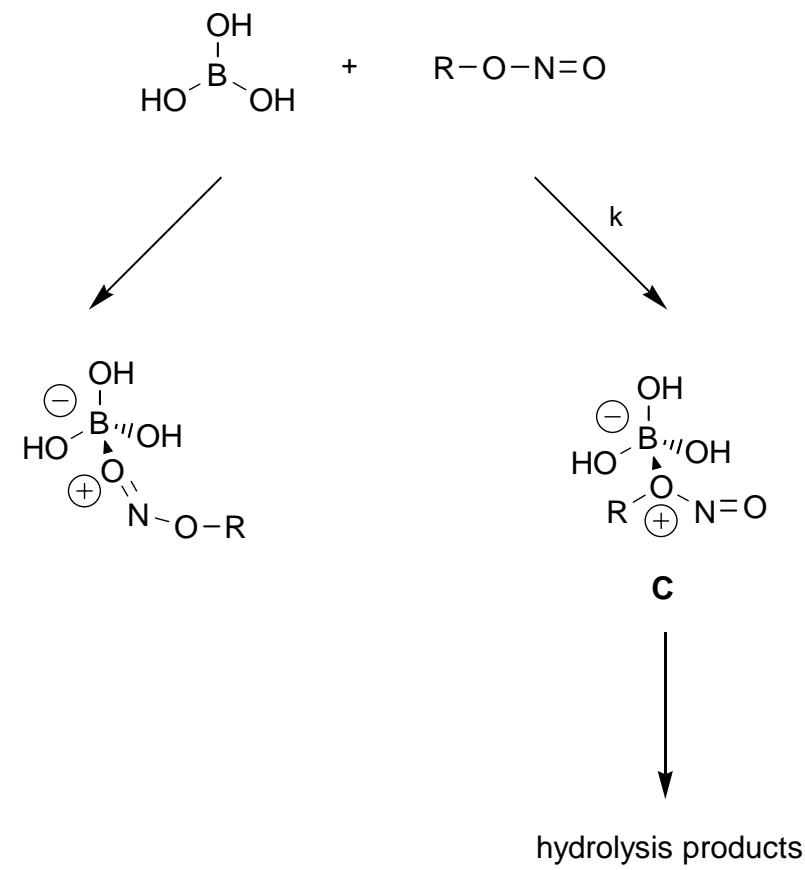

\section{Scheme 2}

The collected data show that in the $\mathrm{pH}$ range investigated $(8.24-10.97)$ the rate of reaction between boric acid and alkyl nitrite depends roughly on the solution $\mathrm{pH}$, and a value of $0.06 \pm$ $0.03 \mathrm{~s}^{-1}$ can be evaluated for the kinetic constant. On the contrary, a regular dependence of the reaction rate on $\beta-\mathrm{CD}$ concentration has been observed (see Figure 4).

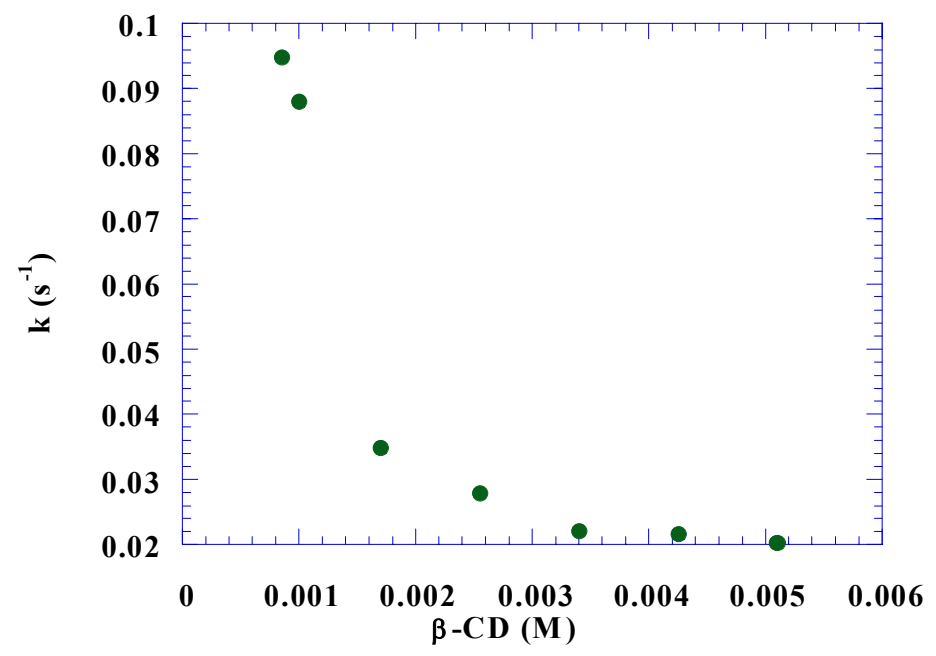

Figure 4. Influence of $\beta-\mathrm{CD}$ concentration on the first fast step of the basic hydrolysis of 2phenylethyl nitrite at $\mathrm{pH}=9.25$. 
Indeed, the reaction is inhibited by $\beta-C D$. Probably, the main effect of $\beta-C D$ on the acidbase reaction between alkyl nitrite and boric acid is the separation of the reagents. It is worthwhile to note that a value of $0.006 \mathrm{~s}^{-1}$ can be calculated from literature data ${ }^{12}$ for the observed kinetic constant for the acid hydrolysis induced by acetic acid. Therefore, taking into account that the acetic acid is a stronger acid than boric acid, one can exclude the possibility that the fast observed reaction is the general-acid-catalyzed hydrolysis of the alkyl nitrite.

We have attempted to resolve the curve reported in Figure 1 by considering it as combination of two exponential curves, as shown by following equation:

$$
A_{t}=\left(A_{0}-A_{1}\right) * e^{-k ’ t}+\left(A_{1}-A_{\infty}\right) * e^{-k ” t}+A_{\infty}(\mathbf{1})
$$

where $A_{0}, A_{t}$, and $A_{\infty}$ are the absorbances of solutions at time $t=0, t=t$, and $t=\infty$ respectively, $A_{1}$ is the absorbance value corresponding to the maximum value of the curve obtained by plotting the absorbance values as a function of the time (see Figure 1), k' and k' are the calculated kinetic constants for the first- and second- slow steps of the reaction, respectively.

The results of the above analysis relative to experimental kinetic runs are reported in Table 1.

Table 1. Rate constants calculated by eq. (1) for the basic hydrolysis of 2-phenylethyl nitrite at various $\mathrm{pH}$ values, at $298 \mathrm{~K}$

\begin{tabular}{lllllll}
\hline $\begin{array}{l}{\left[\mathrm{H}_{3} \mathrm{BO}_{3}\right]} \\
\left(\mathrm{mol} \mathrm{l}^{-1}\right)\end{array}$ & $\begin{array}{l}{\left[\mathrm{B}(\mathrm{OH})_{4}\right]} \\
\left(\mathrm{mol} \mathrm{l}^{-1}\right)\end{array}$ & $\begin{array}{l}{\left[\mathrm{OH}^{-}\right]} \\
\left(\mathrm{mol} \mathrm{l}^{-1}\right)\end{array}$ & $\begin{array}{l}\mathrm{k}^{\prime}{ }_{\mathrm{W}} 10^{4} \\
\left(\mathrm{~s}^{-1}\right)\end{array}$ & $\begin{array}{l}\mathrm{k}^{\prime \prime}{ }_{\mathrm{W}} 10^{6} \\
\left(\mathrm{~s}^{-1}\right)\end{array}$ & $\begin{array}{l}\mathrm{k}_{\mathrm{CD}}^{\prime} 10^{4} \\
\left(\mathrm{~s}^{-1}\right)\end{array}$ & $\begin{array}{l}\mathrm{k}^{\prime \prime} \mathrm{CD}^{1} 10^{6} \\
\left(\mathrm{~s}^{-1}\right)\end{array}$ \\
\hline 0.0119 & 0.0021 & $1.76 \times 10^{-6}$ & 1.9 & 9.7 & 2.3 & 7.7 \\
0.0098 & 0.0042 & $4.25 \times 10^{-6}$ & 3.0 & 6.3 & 2.2 & 8.2 \\
0.0077 & 0.0063 & $8.09 \times 10^{-6}$ & 4.1 & 7.3 & 2.3 & 9.1 \\
0.0057 & 0.0083 & $1.47 \times 10^{-5}$ & 4.4 & 5.4 & 3.8 & 9.9 \\
0.0036 & 0.0104 & $2.91 \times 10^{-5}$ & 6.6 & 2.9 & 5.8 & 12 \\
0.0015 & 0.0125 & $8.08 \times 10^{-5}$ & 13 & 4.2 & 9.8 & 13.5 \\
0.0012 & 0.0138 & $9.31 \times 10^{-4}$ & 49 & 5.8 & 52 & 21 \\
\hline
\end{tabular}

All rate constant values are reproducible within $\pm 5 \%$.

As can be deducted from the trend of the kinetic constants associated with the first slow step of the hydrolysis in the absence $\left(\mathrm{k}_{\mathrm{w}}^{\prime}\right)$ and in the presence $\left(\mathrm{k}_{\mathrm{CD}}^{\prime}\right)$ of $\beta$-cyclodextrin, as a function of the hydroxyl ion concentration, a base catalysis is operative. The comparison between $\mathrm{k}_{\mathrm{w}}^{\prime}$ and $\mathrm{k}^{\prime} \mathrm{CD}$ values seems to indicate a small influence of $\beta-\mathrm{CD}$ on the first slow step of the hydrolysis reaction. However, when the reaction has been carried out at constant hydroxyl ion concentration $\left(1.78^{*} 10^{-5} \mathrm{~mol} \mathrm{l}^{-1}\right)$, on varying the $\beta$-CD concentration $\left(0.001-0.006 \mathrm{~mol} \mathrm{l}^{-1}\right)$, an increase in $\mathrm{k}_{\mathrm{CD}}$ was observed (see Figure 5). 


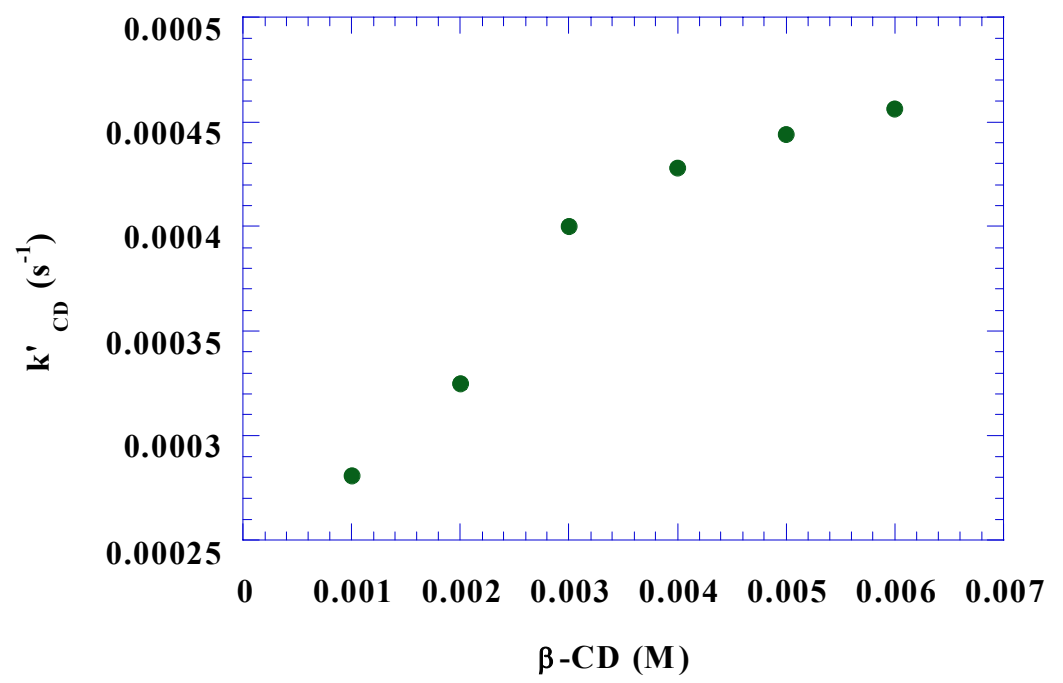

Figure 5. Influence of $\beta-C D$ concentration on the first slow step of the basic hydrolysis of 2phenylethyl nitrite at $\mathrm{pH}=9.25$.

This implies that the presence of $\beta-C D$ favors this step, and that $\beta-C D$ directly participates in the reaction. In other words, the complex $\beta-\mathrm{CD}-\mathrm{RONOB}(\mathrm{OH})_{3}$ is more reactive than the uncomplexed $\mathrm{RONOB}(\mathrm{OH})_{3}$. According to this, the kinetic constant associated with the first step, at a fixed $\mathrm{pH}$ value, increases with increasing $\beta$-CD concentration giving rise to a saturation value. We suggest that the nucleophilic attack of $\mathrm{OH}^{-}$to nitrogen atom of alkyl nitrite (Scheme 3 ) is the step described by the first kinetic constant $k^{\prime}$.

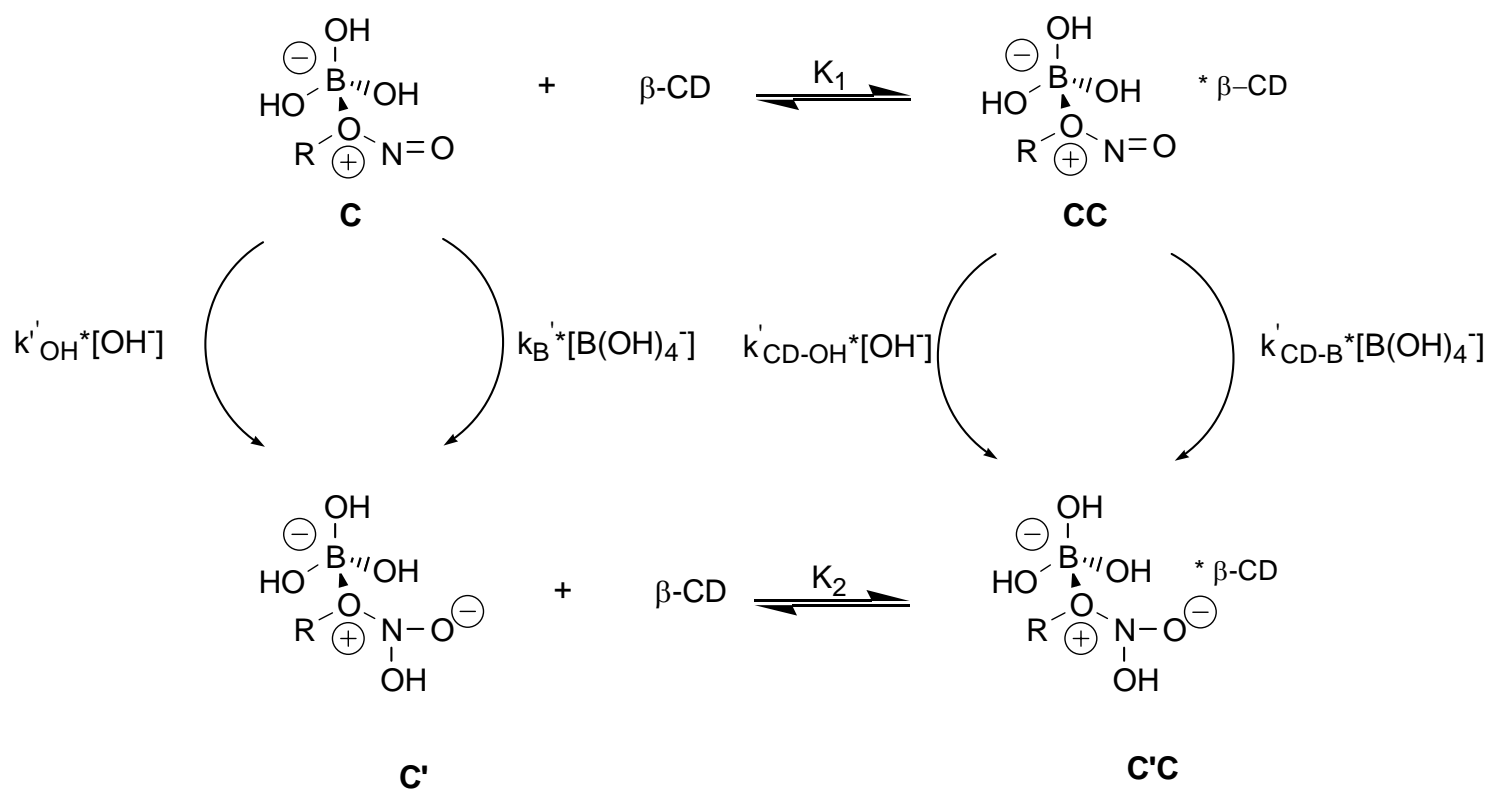

\section{Scheme 3}


According to Scheme 3 the variation of $\mathrm{k}_{\mathrm{CD}}$ with buffer and $\beta-\mathrm{CD}$ concentration may be related to the following equation:

$$
\begin{gathered}
\mathrm{k}^{\prime}{ }_{\mathrm{CD}}=\frac{1}{1+\mathrm{K}_{1} *[\beta-\mathrm{CD}]} *\left[\mathrm{k}_{\mathrm{OH}}^{\prime} *\left[\mathrm{OH}^{-}\right]+\frac{\mathrm{k}_{\mathrm{B}}^{\prime}{ }^{*} \mathrm{~K}_{\mathrm{a}} * \mathrm{C}_{\mathrm{a}} *\left[\mathrm{OH}^{-}\right]}{\mathrm{K}_{\mathrm{w}}+\mathrm{K}_{\mathrm{a}} *\left[\mathrm{OH}^{-}\right]}+\mathrm{k}_{\mathrm{CD}-\mathrm{OH}}^{\prime} * \mathrm{~K}_{1} *\left[\mathrm{OH}^{-}\right] *[\beta-\mathrm{CD}]+\right. \\
\left.+\frac{\mathrm{k}_{\mathrm{CD}-\mathrm{B}}^{\prime} * \mathrm{~K}_{1} * \mathrm{~K}_{\mathrm{a}} * \mathrm{C}_{\mathrm{a}} *\left[\mathrm{OH}^{-}\right]^{*}[\beta-\mathrm{CD}]}{\mathrm{K}_{\mathrm{w}}+\mathrm{K}_{\mathrm{a}} *\left[\mathrm{OH}^{-}\right]}\right]
\end{gathered}
$$

where $\mathrm{K}_{1}$ is the equilibrium constant for the formation of the complex $\mathbf{C C}$, and $\mathrm{k}_{\mathrm{OH}}^{\prime}$ and $\mathrm{k}_{\mathrm{B}}^{\prime}$ are the rate constants relative to the reaction between $\mathbf{C}$ and hydroxyl ion and borate ion, respectively, $\mathrm{K}_{\mathrm{a}}$ is the hydrolysis constant of boric acid, $\mathrm{C}_{\mathrm{a}}$ is the initial concentration of boric acid, $\mathrm{k}^{\prime} \mathrm{CD}-\mathrm{OH}$ and $\mathrm{k}_{\mathrm{CD}-\mathrm{B}}$ are the rate constants associated with the reaction between $\mathbf{C C}$ and hydroxyl ion and borate ion, respectively. From the above equation we obtain the obvious result that the kinetic constants for hydroxyl ion $\left(\mathrm{k}^{\prime}{ }_{\mathrm{OH}}=5.1 \pm 0.2 \mathrm{~mol}^{-1} 1 \mathrm{~s}^{-1} ; \mathrm{k}_{\mathrm{CD}-\mathrm{OH}}^{\prime}=6.3 \pm 0.3 \mathrm{~mol}^{-1} 1 \mathrm{~s} \mathrm{~s}^{-1}\right)$ are much more important than catalytic constants for $\mathrm{B}(\mathrm{OH})_{4}^{-}\left(\mathrm{k}_{\mathrm{B}}=0.059 \pm 0.006 \mathrm{~mol}^{-1} 1 \mathrm{~s} \mathrm{~s}^{-1}\right.$; $\left.\mathrm{k}^{\prime}{ }_{\mathrm{CD}-\mathrm{B}}=0.08 \pm 0.01 \mathrm{~mol}^{-1} 1 \mathrm{~s}^{-1}\right)$.

The $\mathrm{k}^{\prime}{ }_{\mathrm{w}}$ values are roughly influenced by both the $\mathrm{OH}^{-}$and $\beta-\mathrm{CD}$ concentrations. Nevertheless, at a fixed concentration value of $\beta-\mathrm{CD}\left(2 * 10^{-3} \mathrm{~mol} \mathrm{l}^{-1}\right)$ an increase in $\mathrm{OH}^{-}$ concentration favors the reaction (see $\mathrm{k}{ }^{\prime} \mathrm{CD}$ values reported in Table 1). Tentatively, the k" constants could be referred to as a combination of different steps as in Scheme 4: (i) transfer of a hydrogen acid to a water or base molecule and rupture of a nitrogen-oxygen bond; (ii) rupture of a boron-oxygen bond.

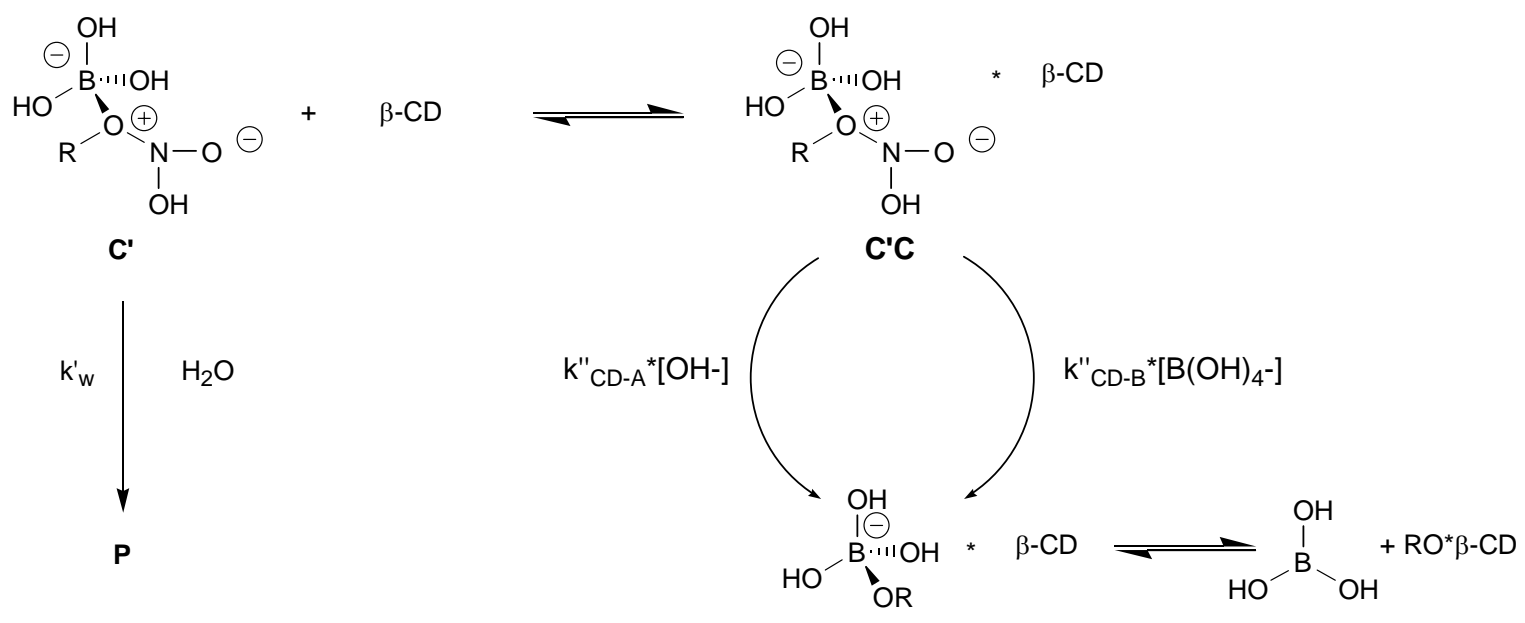

\section{Scheme 4}


From Scheme 4 , the variation of $\mathrm{k}^{\prime \prime}{ }_{\mathrm{CD}}$ with buffer and $\beta-\mathrm{CD}$ concentration may be represented by the following equation:

$$
\mathrm{k}_{\mathrm{CD}}=\frac{1}{1+\mathrm{K}_{2} *[\beta-\mathrm{CD}]} *\left[\mathrm{k}^{\prime \prime}{ }_{\mathrm{w}}+\mathrm{k}^{\prime \prime}{ }_{\mathrm{CD}-\mathrm{OH}^{*}} \mathrm{~K}_{2} *\left[\mathrm{OH}^{-}\right] *[\beta-\mathrm{CD}]+\frac{\mathrm{k}^{\prime \prime}{ }_{\mathrm{CD}-\mathrm{B}}{ }^{*} \mathrm{~K}_{2}{ }^{*} \mathrm{~K}_{\mathrm{a}}{ }^{*} \mathrm{C}_{\mathrm{a}} *\left[\mathrm{OH}^{-}\right]^{*}[\beta-\mathrm{CD}]}{\mathrm{K}_{\mathrm{w}}+\mathrm{K}_{\mathrm{a}} *\left[\mathrm{OH}^{-}\right]}\right]
$$

where $\mathrm{K}_{2}$ is the equilibrium constant for the formation of the complex $\mathbf{C} \mathbf{C}^{\prime}, \mathrm{k}^{\prime \prime}{ }_{\mathrm{w}}, \mathrm{k}^{\prime \prime}{ }_{\mathrm{CD}-\mathrm{OH}}$, and $\mathrm{k}^{\prime \prime}{ }_{\mathrm{CD}-\mathrm{B}}$ are the rate constants relating to the reaction between $\mathbf{C}^{\prime}$ and a water molecule, $\mathbf{C}^{\prime} \mathbf{C}$ and hydroxyl ion, $\mathbf{C}^{\prime} \mathbf{C}$ and borate ion, respectively.

In order to explain the dependence of $\mathrm{k}{ }^{\prime}{ }_{\mathrm{CD}}$ on hydroxyl ion concentration we consider that the acidity of hydrogen atom in $\mathbf{C}^{\prime}$ is sufficiently high, and base catalysis is not observed in the absence of $\beta-C D$. When the reaction is carried out in the presence of $\beta-C D$ the complex formed between $\mathbf{C}^{\prime}$ and $\beta$-CD should have the phenylethyl group inside the cavity and the borate group located outside the cavity (Figure 6).

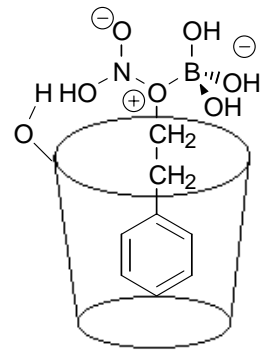

Figure 6. Schematic representation of the inclusion complex $\mathbf{C}^{\prime} \mathbf{C}$.

In this manner, the transfer of hydrogen atom in $\mathbf{C}^{\prime}$ requires the presence of a strong base, and the effect of base concentration is observed as a consequence of both the low polarity of the cavity and a series of hydrogen bonds between $\beta-\mathrm{CD}$ and $\mathbf{C}^{\prime}$.

\section{Conclusions}

In conclusion, to the best of our knowledge this is the first time that the specific interactions between the boric acid and alkyl nitrite are pointed out by kinetic experiments.

The kinetic data we have collected, for both the hydroxy concentration range and mainly as a consequence of the peculiar effect of the boric acid on hydrolysis of alkyl nitrite, are not directly comparable with those reported in the literature. ${ }^{12}$ However, a comparison between the kineticconstant values seems to indicate that in the absence of $\beta$-CD the complexation causes a reduction in the reactivity of the alkyl nitrite. The opposite trend seems to be valid in the presence of $\beta-\mathrm{CD}$. Probably, in this case, owing to the different size of uncomplexed and 
complexed alkyl nitrite, and the relative inclusion depth, the reactive center can be more or less easily available to the attack of base.

\section{Experimental Section}

Materials. The $\beta$-cyclodextrin was purchased from Fluka and used without further purification. It was dried for one day in vacuo over phosphorus pentoxide at $65^{\circ} \mathrm{C}$ and stored in the same apparatus at $40^{\circ} \mathrm{C}$ before use.

Alkyl nitrite 1 was prepared according to the literature, ${ }^{14}$ and then stored under an argon atmosphere over molecular sieves and at a low temperature.

All solutions were prepared using freshly double-distilled water.

Measurements. Kinetic runs were conducted at different $\mathrm{pH}$ values (8.24-10.97), keeping the concentration of boron constant at $0.014 \mathrm{~mol} \mathrm{l}^{-1}$. In this case, increasing volumes of a standard solution of $\mathrm{NaOH}$ were added to the solution of boric acid so as to change the ratio $\mathrm{H}_{3} \mathrm{BO}_{3} / \mathrm{B}(\mathrm{OH})_{4}{ }^{-}$from 6 to 0.16 .

The same experiment was conducted in the presence of a constant concentration of $\beta$ cyclodextrin $\left(0.002 \mathrm{~mol} \mathrm{l}^{-1}\right)$. Furthermore, the reaction was studied keeping constant the $\mathrm{pH}$ value $(\mathrm{pH}=9.25)$ and changing the $\beta$-cyclodextrin concentration from $0.001 \mathrm{~mol}^{-1}$ to $0.006 \mathrm{~mol}$ $1^{-1}$. In this case the ratio between the concentration of boron and the concentration of $\beta$ cyclodextrin was constant, and equal to 7.

The actual $\mathrm{pH}$ of the solutions was recorded using a M82 Radiometer $\mathrm{pH}$ meter equipped with a GK2401C combination electrode.

All experiments were conducted at $298.0 \pm 0.3 \mathrm{~K}$ and at $240 \mathrm{~nm}$. A Hi-Tech SF 61 stoppedflow spectrophotometer was used to record the first fast step of the reaction. A Beckmann DU-6 spectrophotometer was used to record the later slower steps of the reaction.

The solutions used in a typical kinetic run were prepared by adding $50 \mu$ of a dioxane solution of alkyl nitrite (usually $0.024 \mathrm{~mol} \mathrm{l}^{-1}$ ) to $3 \mathrm{ml}$ of buffer solution, kept in a thermostatted cell at $298.0 \mathrm{~K}$. The concentration of 2-phenylethyl nitrite for the kinetic runs was $0.0004 \mathrm{~mol}^{-1}$.

All the kinetic experiments were studied until about $75 \%$ conversion was reached.

The calculated pseudo-first-order rate constants are accurate to within $\pm 5 \%$. They were calculated by the best-fit of the experimental trace. All kinetic data were examined by using computer programs.

\section{Acknowledgements}

This investigation has been supported by University of Palermo (Funds for Selected Research Topics). 


\section{References}

1. Mikhail, V. R.; Inoue Y. Chem. Rev. 1998, 98, 1875.

2. Szejtli, J. Comprehensive Supramolecular Chemistry, Atwood J. L.; Davies J.E.D.; McNicol D. D.; Vögtle F. Eds, Elsevier: Oxford, 1996; Vol. 3, 189.

3. Takahashi, K. Chem. Rev. 1998, 98, 2013.

4. Tee, O. S.; Fedortchenko, A. A.; Soo, P. L. J. Chem. Soc., Perkin Trans. 2 1998, 123.

5. Duchêne, D. In Cyclodextrin and Their Industrial Uses, Editions de Santé: Paris, 1987.

6. (a) Van Etten, R. C.; Sebastian, J. F.; Clews, G. A.; Bender, M. L. J. Am. Chem. Soc. 1967, 69, 3242. (b) Bender, M. L.; Komiyama, M. in Cyclodextrin Chemistry: Springer: Berlin, 1978. (c) D’ Souza, V. T.; Bender, M. L. Acc. Chem. Res. 1987, 20, 146.

7. (a) Tee, O. S.; Gadosy, T. A. J. Chem. Soc., Perkin Trans. 2 1994, 2191. (b) Tee, O. S.; Gadosy, T. A. J. Chem. Soc., Perkin Trans. 2 1994, 715. (c) Tee, O. S.; Gadosy, T. A. Can. J. Chem. 1996, 74, 745. (d) Tee, O. S.; Doga, R. A. J. Chem. Soc., Perkin Trans. 2 1996, 2763. (e) Komiyama, M.; Bender, M. L. J. Am. Chem. Soc. 1997, 99, 802. (f) Granadas, A.; De Rossi, R. H. J. Am. Chem. Soc. 1995, 117, 3690.

8. (a) Breslow, R.; Overmann, L. E. J. Am. Chem. Soc. 1970, 92, 1075. (b) Segel, B.; Pinter, A.; Breslow, R. J. Am. Chem. Soc. 1977, 99, 2309. (c) Colemann, A. W.; Zhang, P.; ParrotLopez, H.; Ling, C. C.; Miocque, M.; Mascrier, L. Tetrahedron Lett. 1991, 32, 3997.

9. (a) D’Anna, F.; Lo Meo, P.; Gruttadauria, M.; Riela, S.; Noto, R. Tetrahedron 2001, 57, 6823. (2) D’Anna, F.; Riela, S.; Lo Meo, P.; Gruttadauria, M.; Noto, R. Tetrahedron Asymmetry 2002, 13, 1755.

10. Bhat, S.; Chandrasekaran, S. Tetrahedron Lett. 1996, 37, 3581.

11. (a) Butler, A. R.; Williams, D. L. H. Chem. Soc. Rev. 1993, 22, 233. (b) Kobzik, L.; Reid, M. B.; Bredt, D. S.; Stamler, J. S. Nature 1994, 372, 546. (c) Snyder, S. H. Nature 1994, 372, 504. (d) Lewis, R. S.; Tannenbaum, S. R.; Deen, W. M. J. Am. Chem. Soc. 1995, 117, 3933.

12. (a) Iglesias, E.; Fernandez, A. J. Chem. Soc., Perkin Trans. 2 1998, 1691. (b) Iglesias, E. J. Am. Chem. Soc. 1998, 120, 13057. (c) Iglesias, E.; Garcìa-Rio, L.; Leis, J. R.; Peña, M. E.; Williams, D. L. H. J. Chem. Soc., Perkin Trans. 2 1992, 1673.

13. (a) Darwent, B. Bond Dissociation Energies in Simple Molecules NSRDS-NBS-31, National Bureau of Standards: Washington, D.C., 1970. Pedley, J. B.; Marshall, E. M. J. Phys. Chem., Ref. Data 1984, 12, 967.

14. Noyes, W. A. Organic Synthesis; Wiley: New York, 1943; Collect. Vol. II. 